Release of water by convective drying from rapeseed at different temperatures

Otpuštanje vode konvekcijskim sušenjem različitim temperaturama iz sjemenki uljane repice

Matin, A., Majdak, T., Grubor, M., Vuković, J., Krička, T.

Poljoprivreda/Agriculture

ISSN: $1848-8080$ (Online)

ISSN: 1330-7142 (Print)

http://dx.doi.org/10.18047/poljo.24.2.7

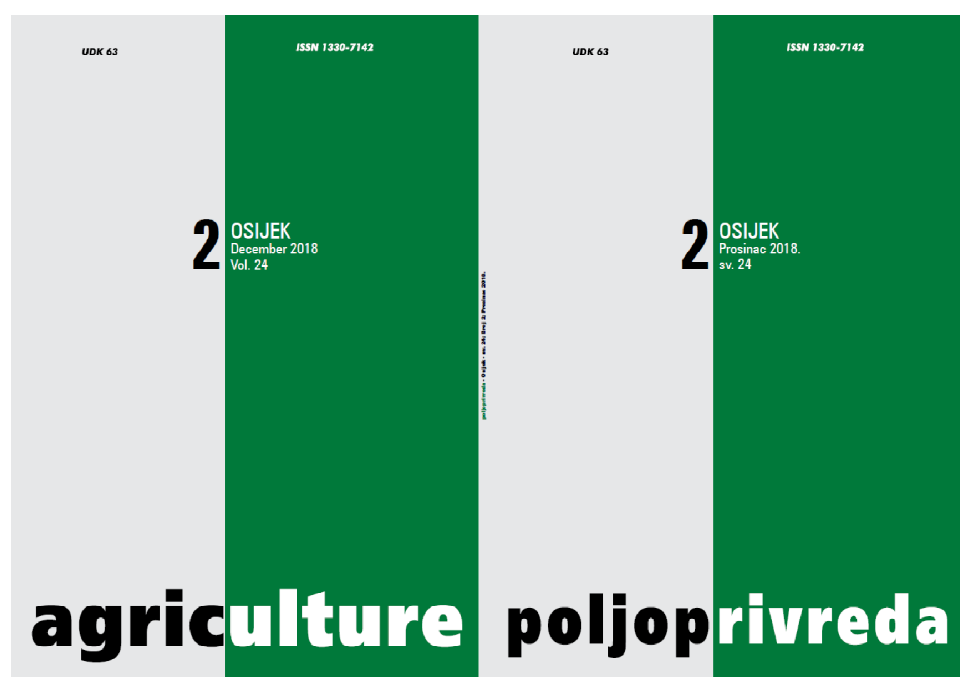

Fakultet agrobiotehničkih znanosti Osijek, Poljoprivredni institut Osijek

Faculty of Agrobiotechnical Sciences Osijek, Agricultural Institute Osijek 
ISSN $1330-7142$

UDK: 635.126:66.047

DOI: $10.18047 /$ poljo.24.2.7

\section{RELEASE OF WATER BY CONVECTIVE DRYING FROM RAPESEED AT DIFFERENT TEMPERATURES}

Matin, A. ${ }^{(1)}$, Majdak, T. ${ }^{(2)}$, Grubor, M. ${ }^{(1)}$, Vuković, J.(1), Krička, T.(1)

Original scientific paper

Izvorni znanstveni članak

\section{SUMMARY}

Rapeseed is one of the most important oil plants in the world. The objective of this research was to analyse the influence of thermal treatment temperature on rapeseed quality, i.e. to investigate the content of oil and free fatty acids in chosen rapeseed hybrids: Turan, Traviata, NK Toccata, NK Petrol, PR 46 W 14 and PR 46 W 15. By their characteristics, these varieties are early, medium-early and mediumlate hybrids. The initial moisture content of the investigated hybrids ranged from $11.28 \%$ to $11.69 \%$. The hybrids were subjected to thermal process of thin-layer convective drying, at temperatures of $40^{\circ}, 60^{\circ}$ and $80^{\circ} \mathrm{C}$ and air velocity of $1.0 \mathrm{~m} / \mathrm{s}$. During the investigation, decomposition of oil due to drying at $80^{\circ} \mathrm{C}$ and increase of free fatty acids concentration above permitted $2 \%$ were observed. Furthermore, based on the obtained results, velocity of water release from seed have been determined, and the drying process was mathematically modelled, whereby determination coefficient (R2) and activation energy were also determined.

Key-words: rapeseed, free fatty acids, convective drying, mathematical modelling, activation energy

\section{INTRODUCTION}

Rapeseed is one of the industrial plants whose economic importance is increasing in Croatia and in the European Union (Kachel-Jakubowska and Szpryngiel, 2008). Only the EU member states (EU-28) produce more than 20 million tonnes of rapeseed making $31 \%$ of the global production (FAOSTAT, 2016). The main factor, which determines usability of rapeseed as animal feed, as raw material for food production and other non-food purposes, can be researched with the aim of improving varieties, seed yield, oil content, proteins and active substances. Changes in the composition and fatty acids content as well as to reduce anti-nutritional components in seeds by treatments can also determinate rapeseed usability (Podkówka, 2004; Bomb et al., 2007; Wakowski, 2006). Factors that significantly influence the oilseeds yield and oil content are hybrid or variety (Gunasekera et al., 2006; Marjanović-Jeromela et al., 2011). High rapeseeds quality can be ensured by an adequate post-harvesting treatment in order to minimise the adverse effects of storing, e.g., high water activity or temperatures and drying times which affects the com- mercial quality of oil, flours and other derivatives (Gely and Santalla, 2000).

For determination of quality drying process, it is crucial to gather a bigger number of information about rapeseed varieties and the influence of chemical properties on drying kinetics (Gely and Santalla, 2000). Different moisture content and changes in chemical composition during drying process influence on drying kinetics (Gupta and Das, 1997; Brooker et al., 1992). The speed and drying quality of agricultural products depend on environment physical characteristics, physical characteristics of the raw material, and the layer thickness (Krička et al., 2007). Drying can be defined as one of the oldest methods for food preservation (Doymaz, 2007). It is probably the main and the most expensive step in post-harvest operations (Cohen and Yang 1995; Mirzaee et al., 2009). The main purpose of drying is to separate excessive water from the product

(1) Assist. Prof. Ana Matin, Mateja Grubor, M. Eng. Agr. (mgrubor@agr. hr), Vuković Jelena, M. Eng. Agr., Prof. Dr. Tajana Krička - University of Zagreb, Faculty of Agriculture, Svetošimunska cesta 25, 10000 Zagreb, Croatia, (2)Tugomir Majdak, M. Eng. Agr. - Ministry of Agriculture, Ulica grada Vukovara 78, 10000 Zagreb, Croatia 
without deteriorating its quality in the process. This procedure provides certain time for preserving the products unchanged and the possibility of using the products throughout the year.

The essential factors for a successful drying process are moisture diffusion, activation energy (Ea), heat and mass transfer, as well as specific energy consumption (Aghbashlo et al., 2008). These factors can be changed by convective drying process and they are influenced by materials and drying parameters (Chayjan et al., 2011). Modelling of the drying process is the most important aspect of the drying technology (Khazaei and Daneshmandi, 2007). In optimisation of dryers the most important factor is prediction of agricultural products drying kinetics under various conditions (Aghbashlo et al., 2008).

In order to optimize the procedure of any thermal treatment method, mathematical models are used to describe the drying kinetics of agricultural products (Karim and Hawlader, 2005). Drying kinetics is significantly influenced by air temperature, air velocity, material size, and drying time (Khazaei et al., 2008).

The researchers describe mathematical modelling of the kinetic process of drying in theoretical, semiempirical and empirical mathematical models of drying of any biological material, depending on drying layer property, namely whether it is an elementary, thin or thick layer (Akpinar and Bicer, 2005). The moisture content of drying materials can be anticipated using drying equations, especially if the drying constant " $k$ " is calculated. Activation energy calculation can be through drying temperature $(\mathrm{T})$ and water release constant $(\mathrm{k})$. Bala (1997) defined the reaction activation energy (Ea) of water release from rapeseed as the energy which must be brought to the water molecules to stir their inter-reactions.

In the recent studies, modelling of the drying kinetics of food has been widely investigated, with focus on rapeseed (Crisp and Woods, 1994), strawberry (Doymaz, 2008), coconut (Madhiyanon et al., 2009), olive pomace (Meziane, 2011), and seed grape (Çakmak and Yıldız, 2011).

The main objective of this work was to investigate the water release in rapeseed hybrids (Turan, Traviata, NK Toccata, NK Petrol, PR 46 W 14, PR 46 W 15) during the thin-layer convective drying at three different drying temperatures $\left(40^{\circ}, 60^{\circ}\right.$ and $\left.80^{\circ} \mathrm{C}\right)$ and to calculate the activation energy of the samples; 3 ) to match the drying data with two mathematical models (Henderson and Pabis and Lewis) and to determine the traits of rapeseed (oil and free fatty acids content) as main indicators of drying precision and quality.

\section{MATERIAL AND METHODS}

This investigation was performed on six rapeseed hybrids grown in the Zagreb County area in the Republic of Croatia. The investigation included early hybrid Turan (KWS), medium-early hybrids Traviata (KWS),
NK Toccata and NK Petrol (Syngenta), and medium-late hybrids PR 46 W 14 as well as PR 46 W 15 (Pioneer). The hybrids were harvested in late June 2017, when samples had moisture level of $11 \%$.

Thermal processing of rapeseeds was conducted in a laboratory dryer where large-scale industrial dryer conditions can be replicated in a thin layer. The laboratory dryer was made in the Agricultural Faculty's Department for agricultural technology, storing and transport in Zagreb. The dryer consists of three units: the dryer's lower section is a $300 \times 350 \times 120 \mathrm{~mm}$ bedplate, housing a fan with $1 \mathrm{~kW}$ heater. The electric heater is fed with alternative current with adaptable voltage, thus, allowing for adjusting air drying temperature as well. Voltage is adapted manually on the regulation transformer, wheras voltmeter, ammeter, and wattmeter are connected in electric circuit. Airflow velocity, or fan regulation, is also controlled manually by using a regulation transformer. Measurements of the air temperature were taken by a PT 100 probe immediately prior to air entering the sample. Air velocity, after passing through the sample layer, was measured by a digital anemometer. Air velocity in the dryer was maintained at $1.0 \mathrm{~ms}^{-1}$, and the samples were dried at three different air temperatures: $40^{\circ}, 60^{\circ}$ and $80^{\circ} \mathrm{C}$.

Based on the obtained values for water release during convective drying, the effective diffusion coefficient was determined, and by using mathematical models Henderson and Pabis and Lewis the drying kinetics of rapeseed was described. The dying data were expressed in terms of the moisture ratio (MR) versus drying time. The activation energy value was obtained by using the equation for calculating drying constant which Henderson and Pabis (1961) proposed based on Arrhenius equation, depending on a temperature, drying constant and activation energy.

Determination of rapeseed moisture content is a method which is based on sample drying in laboratory dryers (INKO ST - 40, Croatia) at $105^{\circ} \mathrm{C}$ in three hours duration, according to the protocol HRN ISO 6540:2002. The oil content was determined using a Soxhlet extractor R 304 Behr Labortechnik GmbH, Germany, according to the protocol HRN ISO 6492:2001. The free fatty acid content was determined by using a gas chromatograph CP-3800, Varian, Palo Alto, CA, according to the protocol HRN EN ISO 5983-2:2010.

Statistical data processing was performed using SAS package in 9.3 version (SAS Institute, Cary, NC, USA) applying the GLM procedure with significance level of $P \geq 0.05$.

\section{RESULTS AND DISCUSSION}

At the harvest time, the seeds' moisture content was above the equilibrium level, around $11.28 \%$ in hybrid Traviata and up to $11.69 \%$ in hybrid NK Toccata.

The results of water release from rape oilseeds are shown in Table 1. 
Table 1. Exponential equations of water release from rapeseed up to reaching constant equilibrium moisture of the investigated hybrids at three drying temperatures

Tablica 1. Eksponencijalne jednadžbe otpuštanja vode iz sjemenki uljane repice do konstantne ravnotežne vlažnosti istraživanih hibrida na tri temperature sušenja

\begin{tabular}{|c|c|c|c|c|}
\hline $\begin{array}{l}\text { Hybrid } \\
\text { Hibrid }\end{array}$ & $\begin{array}{l}\text { Drying air temperature } \\
\text { Temperatura sušenja } \\
\left({ }^{\circ} \mathrm{C}\right)\end{array}$ & $\begin{array}{c}\text { Moisture } \\
\text { Vlaga } \\
(\%)\end{array}$ & $\begin{array}{c}\text { Exponential equations } \\
\text { Eksponencijalna jednadžba }\end{array}$ & $\mathrm{R}^{2}$ \\
\hline Turan & $\begin{array}{l}40 \\
60 \\
80\end{array}$ & 11.38 & $\begin{array}{l}y=10.055 e^{-0,0069 x} \\
y=10.800 e^{-0,0251 x} \\
y=10.851 e^{-0,0434 x}\end{array}$ & $\begin{array}{l}0.945 \\
0.962 \\
0.965\end{array}$ \\
\hline Traviata & $\begin{array}{l}40 \\
60 \\
80 \\
\end{array}$ & 11.28 & $\begin{array}{l}y=10.050 e^{-0,0065 x} \\
y=10.374 e^{-0,0172 x} \\
y=10.614 e^{-0,0431 x}\end{array}$ & $\begin{array}{l}0.929 \\
0.951 \\
0.951\end{array}$ \\
\hline NK Toccata & $\begin{array}{l}40 \\
60 \\
80 \\
\end{array}$ & 11.69 & $\begin{array}{l}y=10.383 e^{-0,0082 x} \\
y=10.218 e^{-0,014 x} \\
y=10.958 e^{-0,0457 x}\end{array}$ & $\begin{array}{l}0.948 \\
0.953 \\
0.945\end{array}$ \\
\hline NK Petrol & $\begin{array}{l}40 \\
60 \\
80\end{array}$ & 11.53 & $\begin{array}{l}y=10.313 e^{-0,0064 x} \\
y=10.411 e^{-0,0182 x} \\
y=10.977 e^{-0,0438 x}\end{array}$ & $\begin{array}{l}0.947 \\
0.933 \\
0.965\end{array}$ \\
\hline PR 46 W 14 & $\begin{array}{l}40 \\
60 \\
80\end{array}$ & 11.38 & $\begin{array}{l}y=10.356^{-0,0078 x} \\
y=10.810 e^{-0,0207 x} \\
y=10.823 e^{-0,0427 x}\end{array}$ & $\begin{array}{l}0.963 \\
0.949 \\
0.961\end{array}$ \\
\hline PR 46 W 15 & $\begin{array}{l}40 \\
60 \\
80\end{array}$ & 11.40 & $\begin{array}{l}y=10.137 e^{-0,0073 x} \\
y=10.565 e^{-0,0224 x} \\
y=10.799 e^{-0,0444 x}\end{array}$ & $\begin{array}{l}0.947 \\
0.965 \\
0.963\end{array}$ \\
\hline
\end{tabular}

Legenda: $y$-vlaga sjemenki, x-vrijeme otpuštanja vode iz sjemenki, R2-koeficijent determinacije

The analysis of the results shows the differences in water release rates between drying temperatures and in the observed hybrids as such. According to the obtained data it can be determined that hybrid NK Toccata releases water faster at all temperature levels, while hybrid Traviata had the lowest water release rate. The deter- mination coefficients were between 0.929 and 0.965 . Similar results were obtained by Kumar et al. in 2010.

Mathematical modelling of rapeseed drying is described by using two most frequent thin layer drying models: Henderson and Pabis and Lewis (Table 2).

Table 2. Mathematical modelling of water release from rapeseed of the investigated hybrids at three drying temperature levels

Tablica 2. Matematičko modeliranje otpuštanja vode iz sjemenki uljane repice istraživanih hibrida na tri temperature sušenja

\begin{tabular}{|c|c|c|c|c|c|c|c|}
\hline \multirow{3}{*}{$\begin{array}{l}\text { Hybrid } \\
\text { Hibrid }\end{array}$} & \multirow{3}{*}{$\mathrm{T}^{\circ} \mathrm{C}$} & \multirow{3}{*}{$\begin{array}{l}\text { Coefficient a } \\
\text { Koeficijent a }\end{array}$} & \multirow{3}{*}{ Exponent $\mathrm{k}$} & \multicolumn{4}{|c|}{ Model } \\
\hline & & & & \multicolumn{2}{|c|}{$\begin{array}{l}\text { Henderson and Pabis } \\
\mathrm{MR}=\mathrm{a} \text { exp (-kt) }\end{array}$} & \multicolumn{2}{|c|}{$\begin{array}{c}\text { Lewis } \\
M R=\exp (-k t)\end{array}$} \\
\hline & & & & MR & $\mathrm{R}^{2}$ & MR & $\mathrm{R}^{2}$ \\
\hline Turan & \multirow{6}{*}{$40^{\circ} \mathrm{C}$} & 0.36699 & 0.06302 & 0.05305 & 0.952 & 0.17622 & 0.937 \\
\hline Traviata & & 0.36601 & 0.14256 & 0.04131 & 0.904 & 0.13933 & 0.887 \\
\hline NK Toccata & & 0.37599 & 0.06618 & 0.05556 & 0.952 & 0.18348 & 0.939 \\
\hline NK Petrol & & 0.37378 & 0.06474 & 0.0540 & 0.951 & 0.17819 & 0.939 \\
\hline PR46W14 & & 0.37263 & 0.06884 & 0.05295 & 0.946 & 0.18791 & 0.932 \\
\hline PR46W15 & & 0.36477 & 0.06353 & 0.05415 & 0.953 & 0.18303 & 0.941 \\
\hline Turan & \multirow{6}{*}{$60^{\circ} \mathrm{C}$} & 0.39581 & 0.12122 & 0.05302 & 0.935 & 0.17511 & 0.916 \\
\hline Traviata & & 0.38004 & 0.24833 & 0.04222 & 0.846 & 0.14342 & 0.833 \\
\hline NK Toccata & & 0.36966 & 0.07865 & 0.05784 & 0.956 & 0.19656 & 0.946 \\
\hline NK Petrol & & 0.37747 & 0.09492 & 0.05603 & 0.951 & 0.18920 & 0.937 \\
\hline PR 46 W 14 & & 0.39552 & 0.11428 & 0.05185 & 0.932 & 0.17005 & 0.907 \\
\hline PR 46 W 15 & & 0.33811 & 0.10352 & 0.05509 & 0.944 & 0.18998 & 0.926 \\
\hline Turan & \multirow{6}{*}{$80^{\circ} \mathrm{C}$} & 0.40015 & 0.13105 & 0.05488 & 0.931 & 0.18695 & 0.905 \\
\hline Traviata & & 0.39154 & 0.33594 & 0.04799 & 0.939 & 0.16541 & 0.923 \\
\hline NK Toccata & & 0.40242 & 0.12187 & 0.05918 & 0.937 & 0.20396 & 0.927 \\
\hline NK Petrol & & 0.40558 & 0.13142 & 0.05650 & 0.930 & 0.19126 & 0.916 \\
\hline PR 46 W 14 & & 0.40094 & 0.13320 & 0.05554 & 0.929 & 0.18820 & 0.917 \\
\hline PR 46 W 15 & & 0.39620 & 0.12777 & 0.05616 & 0.934 & 0.19384 & 0.916 \\
\hline
\end{tabular}


Higher values of moisture ratio (MR) were obtained by changing the Lewis model, in all the observed hybrids and with all applied temperatures. The Lewis equation assumes that the drying rate is proportional to the difference between actual medium moisture content and equilibrium moisture level in the given conditions. Unlike Lewis, Henderson and Pabis introduce the coefficient in the calculation which is directly related to the time of water release and, as such, it gives a more accurate modelling and a significantly better drying curve. Introduction of this parameter allowed for better matching of the experimental and computational data. Hence, the higher values of moisture content ratio (MR) and determination coefficient $\mathrm{R} 2$ by application of these drying models were obtained in thermal treatment of the hybrid NK Toccata. Based on the obtained values, it is proposed to use the Handerson and Pabis formula for a more accurate presentation of drying because the received coefficients are applicable to the investigated hybrids regardless of seeds' moisture. Simulation of thin layer drying, i.e., of diffusion model, is far more appropriate.

The results regarding activation energy in rapeseed water during the drying process, i.e., statistical analysis of influence of the investigated hybrids are shown in Table 3.

Table 3. Values of activation energy in all investigated hybrids

Tablica 3. Vrijednosti energije aktivacije svih istraživanih hibrida

\begin{tabular}{|l|c|c|c|c|c|}
\hline $\begin{array}{l}\text { Hybrid } \\
\text { Hibrid }\end{array}$ & Turan & Traviata & NK Toccata & NK Petrol & R 46 W 14 \\
\hline $\begin{array}{l}\text { Activation energy } \\
\begin{array}{l}\text { Energija aktivacije } \\
\left(\mathrm{kJkg}^{-1}\right)\end{array}\end{array}$ & $17.07^{\mathrm{a}} \pm 2.10$ & $19.80^{\mathrm{a}} \pm 1.58$ & $14.08^{\mathrm{a}} \pm 2.08$ & $16.28^{\mathrm{a}} \pm 2.30$ & $15.31^{\mathrm{a}} \pm 2.68$ \\
\hline
\end{tabular}

Linear relations and the Arrhenius equation were used to define the curves of rapeseed water release constants for each investigated hybrid. The obtained activation energy values showed that the highest energy needed for initiating the water release process was found out in hybrid Traviata $\left(19.80 \mathrm{kJmol}^{-1}\right)$, while hybrid NK Toccata had the lowest activation energy (14.08 $\left.\mathrm{kJmol}^{-1}\right)$. According to various authors who investigated other crops, the obtained values are somewhat lower than the values of drying activation energy. For example, energy of activation in mushrooms ranges from $30.80 \mathrm{kJmol}^{-1}$ to $48.47 \mathrm{kJmol}^{-1}$ (Babalis and Belessiotis, 2004), in berries from $110.84 \mathrm{kJmol}^{-1}$ to $130.61 \mathrm{kJmol}^{-1}$ (Aghbashlo et al., 2008).

The content of initial moisture in hybrids Turan, Traviata, NK Toccata, NK Petrol, PR 46 W 14, PR 46 W 15, as well as the content of oil and free fatty acids (FFA) are shown in Table 4.

Table 4. Moisture content, oil and free fatty acids contents (FFA) in natural samples of all investigated hybrids Tablica 4. Sadržaj vlage te ulja i slobodnih masnih kiselina (SMK) u prirodnom uzorku svih istraživanih hibrida

\begin{tabular}{|c|c|c|c|}
\hline $\begin{array}{l}\text { Hybrid } \\
\text { Hibrid }\end{array}$ & $\begin{array}{c}\text { Moisture (\%) } \\
\text { Vlaga (\%) }\end{array}$ & $\begin{array}{c}\text { Oil (\%) } \\
\text { Ulje (\%) }\end{array}$ & $\begin{array}{l}\text { FFA (\%) } \\
\text { SMK (\%) }\end{array}$ \\
\hline Turan & $11.38 \mathrm{a} \pm 2.09$ & $42.95 \mathrm{a} \pm 2.75$ & $1.45 \mathrm{a} \pm 0.59$ \\
\hline Traviata & $11.28 \mathrm{a} \pm 2.42$ & $40.05 b \pm 3.08$ & $1.85 b \pm 0.17$ \\
\hline NK Toccata & $11.69 b \pm 0.69$ & $41.35 \mathrm{a} \pm 3.18$ & $1.83 \mathrm{a} \pm 0.29$ \\
\hline NK Petrol & $11.53 a \pm 0.81$ & $40.35 a \pm 3.01$ & $1.98 a \pm 4.02$ \\
\hline PR 46 W 14 & $11.38 b \pm 1.23$ & $36.08 \mathrm{a} \pm 3.16$ & $1.58 \mathrm{a} \pm 2.10$ \\
\hline PR 46 W15 & $11.40 a \pm 1.41$ & $41.28 b \pm 2.32$ & $1.88 a \pm 2.77$ \\
\hline
\end{tabular}

It is evident that there are significant differences among the investigated parameters, and these differences enable the obtained results to be compared. The moisture content was in a range from $11.28 \%$ in hybrid Traviata to $11.69 \%$ in hybrid NK Toccata. The oil content was from $36.08 \%$ in hybrid PR $46 \mathrm{~W} 14$ to as high as $42.95 \%$ in hybrid Turan, which meets the Croatian buyout standard. Namely, according to this standard, good quality rapeseed should have the oil content of $40 \%$ (NN 88/2010). Pospisil et al. (2014) determined the average oil content at $45.41 \%$. Kis et al. (2004) state that the oil synthesis is most commonly influenced by climate factors, air temperature, quantity of available moisture in soil at time of soil wetting, and the length of this phase. The FFA content is below the allowed $2 \%$ level for all the investigated hybrids and it is between $1.45 \%$ in Turan and the marginal $1.98 \%$ in NK Petrol.

Table 5 shows that the oil and FFA contents in most hybrids, after thermal treatment, increased in relation to the relevant contents in natural samples. 
Table 5. Contents of moisture, oil and free fatty acids (FFA) of the all investigated rapeseed hybrids after thermal treatment by convective drying

Tablica 5. Sadržaj vlage te ulja i slobodnih masnih kiselina (SMK) svih istraživanih hibrida nakon termičke dorade konvekcijskoga sušenja

\begin{tabular}{|c|c|c|c|}
\hline $\begin{array}{l}\text { Hybrid } \\
\text { Hibrid }\end{array}$ & $\begin{array}{c}\text { Moisture (\%) } \\
\text { Vlaga (\%) } \\
\end{array}$ & $\begin{array}{c}\text { Oil (\%) } \\
\text { Ulje (\%) }\end{array}$ & $\begin{array}{l}\text { FFA (\%) } \\
\text { SMK (\%) }\end{array}$ \\
\hline & \multicolumn{3}{|c|}{$40^{\circ} \mathrm{C}$} \\
\hline Turan & $5.83 a \pm 0.32$ & $45.07 \mathrm{a} \pm 0.65$ & $1.60 \mathrm{a} \pm 1.60$ \\
\hline Traviata & $5.91 \mathrm{a} \pm 0.44$ & $41.23 a \pm 0.79$ & $2.63 \mathrm{a} \pm 2.08$ \\
\hline NK Toccata & $5.97 a \pm 0.46$ & $43.80 \mathrm{a} \pm 0.65$ & $1.87 \mathrm{a} \pm 0.59$ \\
\hline NK Petrol & $5.98 a \pm 0.38$ & $43.20 a \pm 0.80$ & $1.83 \mathrm{a} \pm 2.01$ \\
\hline PR 46 W 14 & $5.93 a \pm 0.42$ & $45.23 a \pm 0.05$ & $1.40 \mathrm{a} \pm 1.56$ \\
\hline \multirow[t]{2}{*}{ PR 46 W 15} & $5.82 a \pm 0.36$ & $44.23 a \pm 0.04$ & $1.57 \mathrm{a} \pm 1.51$ \\
\hline & \multicolumn{3}{|c|}{$60^{\circ} \mathrm{C}$} \\
\hline Turan & $5.97 a \pm 0.28$ & $45.80 b \pm 0.57$ & $1.73 a \pm 0.05$ \\
\hline Traviata & $5.99 a \pm 0.32$ & $40.63 a \pm 0.72$ & $2.73 \mathrm{a} \pm 0.05$ \\
\hline NK Toccata & $5.82 \mathrm{a} \pm 0.32$ & $43.87 b \pm 0.37$ & $2.17 b \pm 0.08$ \\
\hline NK Petrol & $5.84 a \pm 0.42$ & $43.47 b \pm 0.89$ & $1.60 b \pm 0.39$ \\
\hline PR 46 W 14 & $5.97 a \pm 0.38$ & $43.27 a \pm 0.68$ & $1.67 \mathrm{a} \pm 0.79$ \\
\hline \multirow[t]{2}{*}{ PR 46 W 15} & $5.64 a \pm 0.40$ & $42.33 a \pm 0.72$ & $2.33 \mathrm{a} \pm 0.39$ \\
\hline & \multicolumn{3}{|c|}{$80^{\circ} \mathrm{C}$} \\
\hline Turan & $5.77 a \pm 0.44$ & $44.90 b \pm 2.01$ & $2.13 b \pm 0.08$ \\
\hline Traviata & $5.85 a \pm 0.32$ & $41.40 b \pm 1.39$ & $2.73 b \pm 0.03$ \\
\hline NK Toccata & $5.84 a \pm 0.36$ & $43.63 \mathrm{a} \pm 1.69$ & $2.20 \mathrm{a} \pm 2.13$ \\
\hline NK Petrol & $5.93 a \pm 0.36$ & $42.47 \mathrm{a} \pm 1.11$ & $1.83 \mathrm{a} \pm 1.03$ \\
\hline PR 46 W 14 & $5.97 a \pm 0.42$ & $43.40 \mathrm{a} \pm 1.28$ & $1.70 a \pm 1.98$ \\
\hline PR 46 W 15 & $5.75 a \pm 0.48$ & $41.97 \mathrm{a} \pm 1.54$ & $2.60 a \pm 0.89$ \\
\hline
\end{tabular}

The statistical data processing determined that the oil and FFA contents were significantly influenced by temperature levels of $60^{\circ}$ and $80^{\circ} \mathrm{C}$. In drying at temperature of $80^{\circ} \mathrm{C}$ the process of decomposition of fats and development of free fatty acids occurs: the level of free fatty acids exceeds the allowed $2 \%$ in most of the investigated hybrids. This is especially present in hybrid Traviata with the FFA level as high as $2.73 \%$. Lauten and Niepenberg, 1988, state that rapeseed drying, in relation to seed humidity, indicates the problems of an increased free fatty acids content. Kachel-Jakubowska and Szpryngiel, 2008 quote the pre-drying oil content of $40.61 \%$, while thermally treated rapeseed contained $40.36 \%$ oil. These values are in line with this investigation.

\section{CONCLUSION}

1. Rapeseed hybrid Traviata had the fastest, and hybrid NK Toccata the slowest water release rate, which is also corroborated by a higher activation energy value in hybrid NK Toccata.

2. Kinetic curve of drying demonstrates the anticipated trends regarding the conditions in which the process was performed. With increasing temperature levels, the duration times of the process become shorter. The obtained results correlated with the Henderson and Pabis dual-parameter model of thin layer drying.
3. The moisture content was found out to be in the range from $11.28 \%$ in hybrid Traviata to $11.69 \%$ in hybrid NK Toccata. The oil content of the investigated hybrids was between $36.08 \%$ in hybrid PR $46 \mathrm{~W} 14$ up to as much as $42.95 \%$ in hybrid Turan, which meets the Croatian buyout standard.

4. In most hybrids, the oil and FFA contents increased after thermal treatment in relation to natural samples, which is mostly the temperatures influence of $60^{\circ}$ and $80^{\circ} \mathrm{C}$.

\section{ACKNOWLEDGEMENT}

This research was funded by the Croatian Science Foundation, the project no. 3328, "Converting waste agricultural biomass and dedicated crops into energy and added value products - bio-oil and biochar production".

\section{REFERENCES}

1. Aghbashlo, M., \& Samimi-Akhijahani, H. (2008). Influence of drying conditions on the effective moisture diffusivity, energy of activation and energy consumption during the thin-layer drying of berberis fruit (Berberidaceae). Energy Conversion and Management, 49(10), 28652871. https://doi.org/10.1016/j.enconman.2008.03.009

2. Akpinar, E. K., \& Bicer, Y. (2005). Modelling of the drying of eggplants in thin-layers. International Journal of 
Food Science \& Technology, 40(3), 273-281. https://doi. org/10.1111/j.1365-2621.2004.00886.x

3. Bala, B.K. (1997). Drying and Storage of Ceral Grains. Science Publisher, New Hampshire, USA.

4. Bomb, C., McCormick, K., Deurwaarder, E., \& Kåberger, T. (2007). Biofuels for transport in Europe: Lessons from Germany and the UK. Energy Policy, 35(4), 2256-2267. https://doi.org/10.1016/j.enpol.2006.07.008

5. Brooker, D. B., Bakker-Arkema, F. W., \& Hall, C. W. (1992). Drying and storage of grains and oilseeds. Springer Science \& Business Media.

6. Çakmak, G., \& Yıldız, C. (2011). The prediction of seedy grape drying rate using a neural network method. Computers and Electronics in Agriculture, 75(1), 132138. https://doi.org/10.1016/j.compag.2010.10.008

7. Chayjan, R. A., Parian, J. A., \& Esna-Ashari, M. (2011). Modeling of moisture diffusivity, activation energy and specific energy consumption of high moisture corn in a fixed and fluidized bed convective dryer. Spanish journal of agricultural research, 9(1), 28-40.

8. Cohen, J. S., \& Yang, T. C. (1995). Progress in food dehydration. Trends in Food Science \& Technology, 6(1), 20-25.

9. Crisp, J., \& Woods, J. L. (1994). The drying properties of rapeseed. Journal of Agricultural Engineering Research, 57(2), 89-97. https://doi.org/10.1006/ jaer.1994.1008

10. Doymaz, I. (2007). The kinetics of forced convective air-drying of pumpkin slices. Journal of food engineering, 79(1), 243-248. https://doi.org/10.1016/j.jfoodeng.2006.01.049

11. Doymaz, İ. (2008). Convective drying kinetics of strawberry. Chemical Engineering and Processing: Process Intensification, 47(5), 914-919. https://doi.org/10.1016/j. cep.2007.02.003

12. Erenturk, S., \& Erenturk, K. (2007). Comparison of genetic algorithm and neural network approaches for the drying process of carrot. Journal of Food Engineering, 78(3), 905-912. https://doi.org/10.1016/j. jfoodeng.2005.11.031

13. FAOSTAT, 2016. FAOSTAT statistical database.

14. Gely, M. C., \& Santalla, E. M. (2000). Effect of some physical and chemical properties of oilseeds on drying kinetics parameters. Drying Technology, 18(9), 21552166. https://doi.org/10.1080/07373930008917832

15. Gunasekera, C. P., Martin, L. D., Siddique, K. H. M., \& Walton, G. H. (2006). Genotype by environment interactions of Indian mustard (Brassica juncea L.) and canola (B. napus L.) in Mediterranean-type environments: 1. Crop growth and seed yield. European Journal of Agronomy, 25(1), 1-12. https://doi.org/10.1016/j. eja.2005.08.002

16. Gupta, R. K., \& Das, S. K. (1997). Physical properties of sunflower seeds. Journal of Agricultural Engineering Research, 66(1), 1-8. https://doi.org/10.1006/ jaer.1996.0111

17. Kachel-Jakubowska, M., \& Szpryngiel, M. (2008). Influence on drying condition on quality properties of rapeseed. International Agrophysics, 22(4), 327-331.
18. Karim, M. A., \& Hawlader, M. N. A. (2005). Drying characteristics of banana: theoretical modelling and experimental validation. Journal of Food Engineering, 70(1), 35-45. https://doi.org/10.1016/j.jfoodeng.2004.09.010

19. Khazaei, J., Chegini, G. R., \& Bakhshiani, M. (2008). A novel alternative method for modeling the effects of air temperature and slice thickness on quality and drying kinetics of tomato slices: superposition technique. Drying Technology, 26(6), 759-775. https://doi. org/10.1080/07373930802046427

20. Kis, D., Maric, S., Juric, T., Antunovic, M., \& Guberac, V. (2006). Performance of different eruca acid type oil seed rape cultivars in a Croatian agro-environment. Cereal Research Communications, 34(1), 437-440. https://doi. org/10.1556/CRC.34.2006.1.109

21. Krička, T., Voća, N., Janušić, V., Tomić, F., Jukić, Ž., \& Matin, A. (2007). Influence of treatment and storage of rapeseed on its properties as a raw material for biodiesel production. Agriculturae Conspectus Scientificus, 72(3), 173-176.

22. Lauten, H., Grigo, E., \& Niepenberg, K.A. (1988). Rapseine Pflanze mit Zukunft. Rheinischer LandwirtschaftsVerlag.

23. Lewis, W. K. (1921). The rate of drying of solid materials. Industrial \& Engineering Chemistry, 13(5), 427-432. https://doi.org/10.1021/ie50137a021

24. Madhiyanon, T., Phila, A., \& Soponronnarit, S. (2009). Models of fluidized bed drying for thin-layer chopped coconut. Applied Thermal Engineering, 29(14-15), 2849-2854. https://doi.org/10.1016/j.applthermaleng.2009.02.003

25. Marjanović-Jeromela, A., Nagl, N., Gvozdanović-Varga, J., Hristov, N., Kondić-Špika, A., \& Marinković, M. V. R. (2011). Genotype by environment interaction for seed yield per plant in rapeseed using AMMI model. Pesquisa Agropecuária Brasileira, 46(2), 174-181. https://doi. org/10.1590/S0100-204X2011000200009

26. Meziane, S. (2011). Drying kinetics of olive pomace in a fluidized bed dryer. Energy Conversion and Management, 52(3), 1644-1649. https://doi.org/10.1016/j.enconman.2010.10.027

27. Mirzaee, E., Rafiee, S., Keyhani, A., \& Emam-Djomeh, Z. (2009). Determining of moisture diffusivity and activation energy in drying of apricots. Research in Agricultural Engineering, 55(3), 114-120.

28. Page, G.E. (1949). Factors Influencing the Maximum Rates of Air Drying Shelled Corn in Thin layers.

29. Official Gazette $88 / 2010,2010$. Ordinance on the quality control of soybeans, sunflower and rape seed in redemption (in Croatian).

30. Podkówka, W. (2004). The Direction Use of Rape. Biofuel-Glicerine-Feed with Rape. WU Press, Bydgoszcz, Poland.

31. Pospišil, M., Brčić, M., Pospišil, A., \& Butorac, J. (2014). Yield and yield components of investigated rapeseed hybrids and cultivars. Poljoprivreda, 20(1), 3-9.

32. Westerman, P.W., White, G. M., \& Ross, I. J. (1973). Relative humidity effect on the high-temperature drying of shelled corn. Transactions of the ASAE, 16(6), 11361139. https://doi.org/: 10.13031/2013.37715 


\section{OTPUŠTANJE VODE KONVEKCIJSKIM SUŠENJEM RAZLIČITIM TEMPERATURAMA IZ SJEMENKI ULJANE REPICE}

\section{SAŽETAK}

Uljana repica pripada najznačajnijim svjetskim uljaricama. Cilj istraživanja bio je istražiti utjecaj termičke dorade na kvalitetu uljane repice, odnosno analizirati sadržaj ulja i slobodnih masnih kiselina u izabranim hibridima uljane repice: Turan, Traviata, NK Toccata, NK Petrol, PR 46 W 14 i PR 46 W 15. Po svojim karakteristikama, nabrojeni su hibridi rani, srednje rani i srednje kasni hibridi. Početna vlaga istraživanih hibrida kretala se od 11,28 do 11,69\%. Hibridi su podvrgnuti termičkoj doradi konvekcijskim sušenjem u tankome sloju, pri temperaturama 40,60 i $80^{\circ} \mathrm{C}$ i brzini strujanja zraka 1,0 $\mathrm{m} / \mathrm{s}$. Tijekom istraživanja, uočeno je raspadanje ulja tijekom sušenja na $80^{\circ} \mathrm{C}$ te povećanje slobodnih masnih kiselina preko dopuštenih $2 \%$. Nadalje, temeljem dobivenih rezultata, određena je brzina otpuštanja vode te je postupak sušenja matematički modeliran, gdje su određeni koeficijent determinacije (R2) i energija aktivacije vode.

Ključne riječi: uljana repica, slobodne masne kiseline, konvekcijsko sušenje, matematičko modeliranje, energija aktivacije

(Received on 20 July 2018; accepted on 26 November 2018 - Primljeno 20. srpnja 2018.; prihvaćeno 26. studenoga 2018.) 